\title{
The Effect Of Emotional Intelligence And Organizational Commitment On Employee Performance On The Regional Financial Management Agency Of Seluma District
}

\section{Pengaruh Kecerdasan Emosional Dan Komitmen Organisasi Terhadap Kinerja Pegawai Pada Badan Pengelolaan Keuangan Daerah Kabupaten Seluma}

\author{
Juliansyah Putra 1); Sri Handayani 2); Ermy Wijaya 2) \\ 1)Study Program of Management Faculty of Economic, Universitas Dehasen Bengkulu \\ 2) Department of Management, Faculty of Economic, Universitas Dehasen Bengkulu

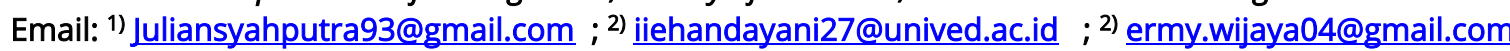

\section{How to Cite :}

Putra, J., Handayani, S., Wijaya, E. (2021). The Effect Of Emotional Intelligence And Organizational Commitment On Employee Performance On The Regional Financial Management Agency Of Seluma District. EMAK: Jurnal Ekonomi Manajemen Akuntansi Dan Keuangan, 3(1). DOI: https://doi.org/10.53697/emak.v2i3

ARTICLE HISTORY

Received [18 Desember 2021]

Revised [29 Desember 2021]

Accepted [1 Januari 2021]

\section{KEYWORDS}

Emotional Intelligence,

Organizational Commitment, Performance

This is an open access article under the $C C-B Y$-SA license

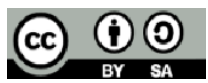

\section{ABSTRAK}

Tujuan penelitian ini adalah Untuk mengetahui pengaruh kecerdasan emosional dan komitmen organisasi secara bersama-sama terhadap kinerja Pegawai pada Badan Pengelolaan Keuangan Daerah Kabupaten Seluma. Sampel dalam penelitian ini sebanyak 74 orang pegawai pada Badan Pengelolaan Keuangan Daerah Kabupaten Seluma. Pengumpulan data menggunakan kuesioner dan metode analisis yang digunakan adalah regresi linier berganda, uji determinasi dan uji hipotesis. Hasil analisis regresi menunjukkan $Y=9,714+0,325 \times 1+$ $0,454 \times 2$, hal ini menggambarkan arah regresi yang positif, artinya terdapat pengaruh positif antara X1 (kecerdasan emosional) dan X2 (komitmen organisasi) terhadap kinerja (Y). Berarti bahwa apabila variabel kecerdasan emosional dan komitmen organisasi meningkat maka akan meningkatkan kinerja. Besarnya nilai koefesien determinasi adalah 0,470. Hal ini berarti bahwa X1 (kecerdasan emosional) dan X2 (komitmen organisasi) berpengaruh terhadap kinerja ( $Y$ ) sebesar $47 \%$ sedangkan sisanya 53\% dipengaruhi oleh variabel-variabel lainnya yang tidak diteliti dalam penelitian ini. Kecerdasan emosional memiliki pengaruh yang signifikan terhadap kinerja pegawai pada Badan Pengelolaan Keuangan Daerah Kabupaten Seluma karena nilai thitung lebih besar dari ttabel $(3,419>1,666)$ dan nilai signifikan sebesar 0,001 lebih kecil dari 0,05. Komitmen organisasi memiliki pengaruh yang signifikan terhadap kinerja pegawai pada Badan Pengelolaan Keuangan Daerah Kabupaten Seluma karena nilai thitung lebih besar dari ttabel $(4,960>1,666)$ dan nilai signifikansi sebesar 0,000 lebih kecil dari 0,05. Hasil uji hipotesis secara simultan (uji F) atau secara bersama-sama memiliki nilai signifikansi sebesar 0,000 kecil dari 0,05 dan Fhitung $>$ Ftabel $(31,473>3,13)$. Artinya variabel kecerdasan emosional dan komitmen organisasi memiliki pengaruh yang signifikan secara bersama-sama terhadap kinerja pegawai pada Badan Pengelolaan Keuangan Daerah Kabupaten Seluma. 
The ipurpose iof ithis istudy iwas ito idetermine ithe ieffect iof iemotional iintelligence iand iorganizational icommitment itogether ion iemployee iperformance iat ithe iRegional iFinancial iManagement iAgency iof iSeluma iRegency. iThe isample iin ithis istudy iwere i74 iemployees iat ithe iRegional iFinancial iManagement iAgency iof iSeluma iRegency. iCollecting idata iusing ia iquestionnaire iand ithe ianalytical imethod iused iis imultiple ilinear iregression, idetermination itest iand ihypothesis itesting. $i$ iThe iresults iof ithe iregression ianalysis ishowed iY $i=i 9.714 i+i 0.325 \times 1 i+$ i0.454 iX2, ithis idescribes ia ipositive iregression idirection, imeaning ithat ithere iis ia ipositive iinfluence ibetween iX1 i(emotional iintelligence) iand iX2 i(organizational icommitment) ion iperformance i(Y). ilt imeans ithat iif ithe ivariables iof iemotional iintelligence iand iorganizational icommitment iincrease, iit iwill iincrease iperformance. iThe ivalue iof ithe icoefficient iof idetermination iis 10.470 . iThis imeans ithat iX1 i(emotional iintelligence) iand iX2 i(organizational icommitment) iaffect iperformance $i(Y)$ iby i47\% iwhile ithe iremaining i53\% iis iinfluenced iby iother ivariables inot iexamined iin ithis istudy. iEmotional iintelligence ihas ia isignificant ieffect ion iemployee iperformance iat ithe iRegional iFinancial iManagement iAgency iof iSeluma iRegency ibecause ithe itcount iis igreater ithan ittable i(3.419 i> i1.666) iand ithe isignificant ivalue iis i0.001 iless ithan i0.05. iOrganizational icommitment ihas ia isignificant iinfluence ion iemployee iperformance iat ithe iRegional iFinancial iManagement iAgency iof iSeluma iRegency ibecause ithe ivalue iof itcount iis igreater ithan ittable $i(4.960 \mathrm{i}>$ i1.666) iand ithe isignificance ivalue iof i0.000 iis iless ithan i0.05. iThe iresults iof ihypothesis itesting isimultaneously i(F itest) ior itogether ihave ia isignificance ivalue iof i0.000 iwhich iis ismaller ithan i0.05 iand iFcount is iFtable i(31.473 i> i3.13). iThis imeans ithat ithe ivariables iof iemotional iintelligence iand iorganizational icommitment ihave ia isignificant iinfluence itogether ion iemployee iperformance iat ithe iSeluma iRegency iRegional iFinancial iManagement iAgency

\section{PENDAHULUAN}

Paradigma lama yang menganggap bahwa IQ (Intelligence Quotient) atau Kecerdasan Intelektual sebagai satu - satunya tolak ukur kecerdasan seseorang, seringkali dijadikan parameter keberhasilan kinerja sumber daya manusia di suatu kelompok tertentu. Namun, pernyataan ini digugurkan dengan hadirnya paradigma lain mengenai kecerdasan yang turut menentukan keberhasilan seseorang. Goleman (2015:42) menyimpulkan bahwa "Pencapaian Kinerja ditentukan hanya 20 persen dari IQ, sedangkan 80 persen lagi ditentukan oleh kecerdasan emosi (El/Emotional Intelligence)". Dengan kata lain, kecerdasan emosional atau Emosional Quotient (EQ) ini memberikan peranan dalam mengarahkan pegawai untuk bersikap adaptif dalam menghadapi sesuatu, mawas diri dan selalu mengevaluasi dirinya agar selalu selaras dengan kepentingan organisasi atau instansi pemerintahan.

Komitmen organisasi juga dapat mempengaruhi kinerja. Komitmen organisasi sebagai salah satu sikap dalam pekerjaan didefinisikan sebagai orientasi seseorang terhadap organisasi dalam arti kesetiaan, identifikasi, dan keterlibatan (Muchlas, 2014:47). Dalam hal ini, karyawan mengidentifikasikan secara khusus organisasi beserta tujuannya dan berharap dapat bertahan sebagai anggota dalam organisasi tersebut. Jadi, yang dimaksud dengan keterlibatan tugas/kerja itu berarti mengidentifikasikan organisasi/perusahaan yang memperkerjakan seseorang. 
Badan Pengelolaan Keuangan Daerah Kabupaten Seluma merupakan instansi pemerintah yang memiliki tugas mengatur keuangan daerah berdasarkan asas otonomi dan tugas pembantuan. Pelaksanaan tugas dan fungsi dari Badan Pengelolaan Keuangan Daerah Kabupaten Seluma harus memiliki sumber daya manusia yang handal sehingga mampu melaksanakan semua tugas dan tanggung jawab yang diberikan kepadanya.

Tingginya tanggung jawab seorang Pegawai karena banyaknya tugas dan tanggungjawab yang harus diselesaikan tepat waktu. Pada kenyataannya dapat dilihat masih kurangnya kecerdasan emosional yang dimiliki oleh pegawai Badan Pengelolaan Keuangan Daerah Kabupaten Seluma. Hal ini berdasarkan hasil pra penelitian yang dilakukan dengan cara wawancara terhadap pegawai pada Badan Pengelolaan Keuangan Daerah Kabupaten Seluma. Hasil wawancara dengan Ibu Werda Susanti mengatakan bahwa pegawai masih merasakan kepanikan pada saat adanya tekanan kerja yang tinggi baik dari pimpinan maupun dari pegawai lainnya. Tekanan kerja dan rutinitas kerja memerlukan dukungan mental yang mampu mengendalikan dan mengelola emosi secara positif, serta mampu memotivasi diri sendiri, mampu mengenali emosi orang lain, dan mampu membina hubungan dengan orang lain, sehingga akan terjalin hubungan saling percaya dan saling membantu antara pegawai dengan sesama pegawai dan antara pegawai dengan pimpinan.

Berdasarkan fenomena yang ada dari latar belakang yang diuraikan diatas, maka peneliti tertarik untuk melakukan penelitian dengan judul "Pengaruh Kecerdasan Emosional dan Komitmen Organisasi Terhadap Kinerja Pegawai pada Badan Pengelolaan Keuangan Daerah Kabupaten Seluma"

\section{LANDASAN TEORI}

\section{Kecerdasan Emosional}

Menurut Shapiro (2016:34), menyatakan bahwa kecerdasan emosional ialah himpunan bagian dari kecerdasan sosial yang melibatkan kemampuan memantau perasaan sosial yang melibatkan kemampuan pada orang lain, memilah-milah semuanya dan menggunakan informasi ini untuk membimbing pikiran dan tindakan..

\section{Komitmen Organisasi}

Menururt Sopiah $(2015 ; 156)$, "bahwa komitmen terhadap organisasi melibatkan tiga sikap : (1) Identifikasi dengan tujuan organisasi, (2) Perasaan keterlibatan dalam tugas-tugas organisasi, dan (3) Perasaan setia terhadap organisasi". Hal ini berarti karyawan yang komit terhadap organisasi memandang nilai dan kepentingan mengintegrasikan tujuan pribadi dan organisasi, sehingga tujuan organisasi merupakan tujuan pribadinya. Pekerjaan yang menjadi tugasnya dipahami sebagai kepentingan pribadi, dan memiliki keinginan untuk selalu loyal demi kemajuan organisasi

\section{Kinerja}

Mangkunegara (2015:67), mengatakan kinerja merupakan hasil kerja secara kualitas dan kuantitas yang dicapai oleh seseorang dalam melaksanakan fungsinya sesuai dengan tanggungjawab yang diberikan kepadanya. Siagian (2015:227) mendefinisikan kinerja sebagai suatu keseluruhan kemampuan seseorang untuk bekerja sedemikian rupa sehingga mencapai tujuan kerja secara optimal dan berbagai sasaran yang telah diciptakan dengan pengorbanan yang secara rasio lebih kecil dibandingkan dengan hasil yang dicapai.

\section{METODE PENELITIAN}

\section{Metode Analisis}




\section{Regresi Linear Berganda}

Analisis regresi linear berganda untuk menentukan ketepatan prediksi apakah ada pengaruh yang kuat antara variabel independen $(Y)$ dengan variabel dependen (X1 dan X2). Bentuk umum persamaan regresi berganda adalah sebagai berikut (Sugiyono, 2015:192):

$$
Y=a+b 1 X 1+b 2 X 2+e
$$

Keterangan :

$$
\begin{array}{ll}
\mathrm{Y} & =\text { Kinerja } \\
\mathrm{X} 1 & =\text { Kecerdasan Emosional } \\
\mathrm{X} 2 & =\text { Komitmen organisasi } \\
\mathrm{a} & =\text { Nilai konstanta } \\
\mathrm{e} & =\text { erorr }
\end{array}
$$

\section{Pengujian Hipotesis}

Uji t

Uji t pada dasarnya menunjukkan seberapa jauh pengaruh satu variabel bebas secara individual dalam menerangkan variasi variabel terikat.

Uji $F$

Uji $\mathrm{F}$ dilakukan untuk mengetahui pengaruh variabel bebas secara bersama-sama terhadap variabel terikat. Dasar pengambilan keputusannya (Ghozali, 2015:48) adalah dengan menggunakan angka probabilitas signifikansi,

\section{HASIL DAN PEMBAHASAN}

\section{Analisis Regresi Linier Berganda}

Analisis regresi linier berganda digunakan untuk mengetahui besarnya pengaruh

\begin{tabular}{|c|c|c|c|c|c|c|}
\hline \multirow{2}{*}{\multicolumn{2}{|c|}{ Model }} & \multicolumn{2}{|c|}{ Unstandardized Coefficients } & \multirow{2}{*}{$\begin{array}{c}\text { Standardized } \\
\text { Coefficients } \\
\text { Beta }\end{array}$} & \multirow[b]{2}{*}{$\mathrm{t}$} & \multirow[b]{2}{*}{ Sig. } \\
\hline & & B & Std. Error & & & \\
\hline \multirow[t]{3}{*}{1} & (Constant) & 9.714 & 3.947 & & 2.455 & .017 \\
\hline & Kecerdasan emosional & .325 & .095 & 328 & 3.419 & .001 \\
\hline & Komitmen organisasi & .454 & .092 & .476 & 4.960 & .000 \\
\hline
\end{tabular}
kecerdasan emosional dan komitmen organisasi terhadap kinerja pegawai pada Badan Pengelolaan Keuangan Daerah Kabupaten Seluma. Perhitungan statistik dalam analisis regresi berganda dijelaskan pada tabel 1 berikut ini:

Tabel 1. Hasil Uji Regresi Berganda

\section{Coefficients $^{a}$}

a. Dependent Variable: Kinerja

Sumber: Output SPSS Versi 21.0, 2021

Dari hasil perhitungan regresi linear berganda dengan menggunakan program SPSS 21.00 pada Tabel 9 maka dapat diperoleh perseamaan regresi linier berganda sebagai berikut : $Y=9,714+0,325 X 1+0,454 X 2$

Persamaan regresi tersebut dapat dijelaskan sebagai berikut :

1. Nilai konstanta 9,714 mempunyai arti bahwa apabila variabel Kecerdasan emosional (X1) dan komitmen organisasi (X2) dianggap sama dengan nol (0) maka variabel kinerja (Y) akan tetap sebesar 9,714.

2. Pengaruh Kecerdasan emosional (X1) terhadap kinerja (Y)

22 | Juliansyah Putra, Sri Handayani, Ermy Wijaya; The Effect Of Emotional Intelligence And... 
Nilai koefesien regresi variabel X1 (Kecerdasan emosional) adalah sebesar 0,325, dengan asumsi apabila X1 (Kecerdasan emosional) mengalami peningkatan sebesar satu-satuan, maka Y (Kinerja) juga akan mengalami peningkatan sebesar 0,325.

3. Pengaruh Komitmen organisasi $(X 2)$ terhadap Kinerja $(Y)$

Nilai koefesien regresi variabel X2 (komitmen organisasi) adalah sebesar 0,454 , dengan asumsi apabila X2 (komitmen organisasi) mengalami peningkatan sebesar satu-satuan maka $Y$ (kinerja) akan mengalami peningkatan sebesar 0,454.

\section{Koefisien Determinasi (R2)}

Koefisien determinasi ini digunakan untuk mengetahui seberapa besar pengaruh variabel-variabel bebas terhadap variabel terikatnya. Nilai koefisien determinasi ditentukan dengan nilai $\mathrm{R}$ square.

Tabel 2. Koefesien Determinasi

\section{Model Summary}

\begin{tabular}{|l|l|l|l|l|}
\hline Model & $R$ & R Square & $\begin{array}{l}\text { Adjusted } \\
\text { Square }\end{array}$ & $\begin{array}{l}\text { RStd. Error of the } \\
\text { Estimate }\end{array}$ \\
\hline 1 & $.686^{\mathrm{a}}$ & .470 & .455 & 2.419 \\
\hline
\end{tabular}

a. Predictors: (Constant), Komitmen organisasi, Kecerdasan emosional

Sumber: Output SPSS Versi 21.0, 2021

Berdasarkan Tabel 2 untuk nilai koefesien determinasi menggunakan model R square. Dari hasil perhitungan dengan menggunakan SPSS dapat diketahui nilai koefesien determinasi dari R square yaitu sebesar 0,470. Hal ini berarti bahwa X1 (kecerdasan emosional) dan X2 (komitmen organisasi) berpengaruh terhadap kinerja $(Y)$ sebesar $47 \%$ sedangkan sisanya $(100-47 \%=53 \%)$ dipengaruhi oleh variabel-variabel lainnya yang tidak diteliti dalam penelitian ini.

\section{Pengujian Hipotesis Secara Partial (Uji t)}

Dari hasil perhitungan Tabel 1 maka dapat dijelaskan sebagai berikut:

1. Variabel X1 (Kecerdasan emosional)

Hasil pengujian untuk variabel $\mathrm{X} 1$ (kecerdasan emosional) menunjukkan nilai thitung = 3,419 kemudian dibandingkan dengan nilai ttabel dengan level of signifikan ditetapkan 95\% dengan perhitungan satu arah dan $\mathrm{dk}=\mathrm{n}-\mathrm{k}=74-2=72$, diketahui nilai ttabel sebesar 1,666. Maka thitung lebih besar dari ttabel $(3,419>1,666)$ dengan nilai signifikansi sebesar 0,001 $<0,05$. Karena thitung $>$ ttabel dan nilai signifikansi lebih kecil dari 0,05, maka H0 ditolak dan Ha diterima. Artinya X1 (kecerdasan emosional) memiliki pengaruh yang signifikan terhadap kinerja $(\mathrm{Y})$ pegawai pada Badan Pengelolaan Keuangan Daerah Kabupaten Seluma.

2. Variabel X2 (Komitmen organisasi)

Hasil pengujian untuk variabel $\mathrm{X} 2$ (komitmen organisasi) menunjukkan nilai thitung = 4,960 kemudian dibandingkan dengan nilai ttabel dengan level of signifikan ditetapkan 95\% dengan perhitungan satu arah dan $\mathrm{dk}=\mathrm{n}-\mathrm{k}=74-2=72$, diketahui nilai ttabel sebesar 1,666. Maka thitung lebih besar dari ttabel $(4,960>1,666)$ dengan nilai signifikansi sebesar $0,000<0,05$. Karena thitung $>$ ttabel dan nilai signifikansi lebih kecil dari 0,05 , maka HO ditolak dan Ha diterima. Artinya X2 (komitmen organisasi) memiliki 
p-ISSN 2798-0499 e-ISSN 2798-0502

pengaruh yang signifikan terhadap kinerja (Y) pegawai pada Badan Pengelolaan Keuangan Daerah Kabupaten Seluma.

Pengujian Hipotesis Secara Simultan (Uji F)

Tabel 3. Hasil Uji $\mathrm{F}$

ANOVA $^{a}$

\begin{tabular}{|ll|l|l|l|l|l|}
\hline \multicolumn{1}{|c|}{ Model } & \multicolumn{1}{c|}{ Sum iof iSquares } & df & \multicolumn{1}{c|}{ Mean iSquare } & \multicolumn{1}{c|}{ S } & \multicolumn{1}{c|}{ Sig. } \\
\hline 1 & Regression & 368.362 & 2 & 184.181 & 31.473 & $.000^{\mathrm{b}}$ \\
& Residual & 415.489 & 71 & 5.852 & & \\
& Total & 783.851 & 73 & & & \\
\hline
\end{tabular}

a. Dependent Variable: Kinerja

b. Predictors: (Constant), Komitmen organisasi, Kecerdasan emosional

Sumber: Output SPSS Versi 21.0, 2021

Berdasarkan Tabel 3 hasil perhitungan statistik menunjukkan $F$ hitung $=31,473$ sedangkan Ftabel (df1=k-1=3-1=2, sedangkan $\mathrm{df2}=\mathrm{n}-\mathrm{k}=74-3=71$, alpha $=5 \%$ ) adalah sebesar 3,13, berarti diperoleh Fhitung $>$ Ftabel $(31,473>3,13)$ dengan nilai signfikan sebesar 0,000. Karena nilai Fhitung $>$ Ftabel dan nilai signifikan sebesar 0,000 0,05 menunjukkan bahwa secara simultan X1 (kecerdasan emosional) dan X2 (komitmen organisasi) mempunyai pengaruh yang signifikan terhadap kinerja $(Y)$. Berdasarkan hasil uji simultan maka HO ditolak dan Ha diterima, artinya antara variabel-variabel bebas yaitu X1 (kecerdasan emosional) dan X2 (komitmen organisasi) mempunyai pengaruh yang signifikan secara simultan terhadap kinerja pegawai (Y) pada Badan Pengelolaan Keuangan Daerah Kabupaten Seluma.

\section{Pengaruh Kecerdasan Emosional Terhadap Kinerja}

Hasil pengujian pada penelitian ini menunjukkan bahwa terdapat pengaruh yang signifikan antara kecerdasan emosional terhadap kinerja pegawai pada Badan Pengelolaan Keuangan Daerah Kabupaten Seluma, karena nilai signifikan sebesar 0,001 kecil dari 0,05 dan thitung lebih besar dari ttabel $(3,419>1,666)$. Hal ini menggambarkan bahwa semakin meningkat kecerdasan emosional maka kinerja pegawai pada Badan Pengelolaan Keuangan Daerah Kabupaten Seluma juga akan meningkat.

Pegawai menilai kecerdasan emosional mampu meningkatkan kinerja pegawai dalam bekerja. pegawai telah mampu meghadapi kesulitan dalam bekerja sehingga pegawai mampu mengerjakan semua tugas yang diberikan kepadanya, pegawai menyadari kelebihan dan keselumaangan yang ada dalam dirinya sehingga mereka bisa untuk menghadapi masalah yang timbul dalam bekerja, namun terkadang karena banyaknya pekerjaan membuat pegawai selumaang percaya diri pada kemampuan yang mereka miliki. Untuk itu pegawai harus memiliki kepercayaan pada dirinya bahwa dengan keterampilan dan ilmu yang dimiliki serta pengalaman dalam bekerja mereka mampu menyelesaikan semua pekerjaan yang diberikan kepadanya. Untuk peningkatan kepercayaan diri dari pegawai hal yang dapat dilakukan adalah dengan memberikan pengarahan kepada pegawai dan memberikan keyakinan kepada pegawai bahwa dengan kemampuan yang mereka miliki mereka mampu untuk menyelesaikan semua pekerjaannya.

\section{Pengaruh Komitmen Organisasi Terhadap Kinerja}

Hasil pengujian pada penelitian ini menunjukkan bahwa terdapat pengaruh yang signifikan antara komitmen organisasi terhadap kinerja karena nilai signifikan sebesar 0,000 lebih kecil dari i0,05 idan ithitung ilebih ibesar idari ittabel i(4,960 i> i1,666). iHal iini imenggambarkan ibahwa isemakin imeningkat ikomitmen iorganisasi imaka ikinerja ipegawai ipada iBadan iPengelolaan iKeuangan iDaerah iKabupaten iSeluma ijuga iakan isemakin imeningkat. i 
iArtinya idengan iadanya ikomitmen iyang itinggi iterhadap iorganisasi iakan imenciptakan ikesetian iPegawai iterhadap iBadan iPengelolaan iKeuangan iDaerah iKabupaten iSeluma idan itidak iberkeinginan iuntuk ipindah ikerja isehingga iPegawai idapat ibekerja ilebih ifocus idan idapat imeningkatkan ikinerja iPegawai

\section{KESIMPULAN DAN SARAN}

\section{Kesimpulan}

1. Hasil analisis regresi menunjukkan $Y=9,714+0,325 X 1+0,454 \quad X 2$, hal ini menggambarkan arah regresi yang positif, artinya terdapat pengaruh positif antara X1 (kecerdasan emosional) dan X2 komitmen organisasi) terhadap kinerja (Y). Berarti bahwa apabila variabel kecerdasan emosional dan komitmen organisasi meningkat maka akan meningkatkan kinerja.

2. Besarnya nilai koefesien determinasi adalah 0,470. Hal ini berarti bahwa X1 (kecerdasan emosional) dan X2 (komitmen organisasi) berpengaruh terhadap kinerja (Y) sebesar 47\% sedangkan sisanya $53 \%$ dipengaruhi oleh variabel-variabel lainnya yang tidak diteliti dalam penelitian ini.

3. Kecerdasan emosional memiliki pengaruh yang signifikan terhadap kinerja pegawai pada Badan Pengelolaan Keuangan Daerah Kabupaten Seluma karena nilai thitung lebih besar dari ttabel $(3,41>1,666)$ dan nilai signifikan sebesar 0,001 lebih kecil dari 0,05.

4. Komitmen organisasi memiliki pengaruh yang signifikan terhadap kinerja pegawai pada Badan Pengelolaan Keuangan Daerah Kabupaten Seluma karena nilai thitung lebih besar dari ttabel $(4,960>1,666)$ dan nilai signifikansi sebesar 0,000 lebih kecil dari 0,05

5. Hasil uji hipotesis secara simultan (uji F) atau secara bersama-sama memiliki nilai signifikansi sebesar 0,000 kecil dari 0,05 dan Fhitung > Ftabel $(31,473>3,13)$. Artinya variabel kecerdasan emosional dan komitmen organisasi memiliki pengaruh yang signifikan secara bersama-sama terhadap kinerja pegawai pada Badan Pengelolaan Keuangan Daerah Kabupaten Seluma.

\section{Saran}

1. Diharapkan kepada Pegawai Badan Pengelolaan Keuangan Daerah Kabupaten Seluma untuk dapat mengendalikan emosi dalam bekerja, dan bekerja dengan teliti karena dapat meningkatkan kecerdasan emosional.

2. Disarankan kepada Pegawai Badan Pengelolaan Keuangan Daerah Kabupaten Seluma untuk lebih memperhatikan instansi dengan cara memberikan ide-ide cemerlang dan mendahulukan kepentingan kantor dari kepentingan pribadi.

\section{DAFTAR PUSTAKA}

Ambar, Teguh Sulistiyani dan Rosidah. 2016. Manajemen Sumber Daya Manusia. Yogyakarta : Graha Ilmu.

Ariesta. 2016. Pengaruh Kecerdasan Emosional Dan Organizational Citizenship Behavior (OCB) Terhadap Kinerja Peternak Ayam Ras Pedaging. Skripsi. Universitas Airlangga

Danim, Sudarwan. 2016. Kinerja Staf dan Organisasi. Bandung : Pustaka Setia

Erdiyanti. 2018. Pengaruh Kecerdasan Emosional dan Komitmen Organisasi Terhadap Kinerja Guru di SMA Negeri 1 Kendari. Jurnal Shautut Tarbiyah, Ed. Ke-39 Th. XXIV

Ghozali, Imam. 2015. Aplikasi Analisis Multivariate Dengan Program SPSS. Semarang: Badan Penerbit Universitas Diponegoro

Goleman Daniel. 2015. Emotional Intelligence. Jakarta : Gramedia Utama

Luthans, Fred. 2014. Perilaku Organisasi. Edisi Sepuluh. Diterjemahkan oleh : Vivin Andhika Yuwono; Shekar Purwanti; Th.Arie Prabawati; dan Winong Rosari. Yogyakarta : Andi 
Mahyudin Fajri. 2017. Hubungan Budaya Organisasi dan Komitmen Organisasi dengan Kinerja Pegawai Pada Bagian Administrasi Keuangan Sekretariat Daerah Provinsi Bengkulu. Skripsi. Universitas Dehasen

Mangkunegara. Anwar Prabu, 2015. Manajemen Sumber Daya Manusia Perusahaan. Bandung: PT. Remaja Rosdakarya

Muchlas Samanii, 2014. Konsep dan Model Pendidikan Karakter. Bandung Remaja Rosdakarya Narimawati, Umi. 2014. Riset Manajemen Sumber Daya Manusia. Jakarta : Agung Media Prawirosentono, Suryadi. 2016. Kebijakan Kinerja Karyawan. Yogyakarta:BPFE.

Selviyani. 2019. Employee Success through the Level of Emotional Intelligence and Spiritual Intelligence. Management Analysis Journal 8 (3)

Shapiro Lawrence, E. 2016. Mengajarkan Kecerdasan Emosional Pada Anak. Jakarta : Gramedia Utama

Soekidjan, 2016. Manjaemen Sumber Daya Manusia . Jakarta : Bumi Aksara

Sopiah. 2015. Perilaku Organisasi, Yogyakarta: Andi Offset.

Sugiyono, 2015. Statistika Untuk Penelitian. Cetakan keenam, Penerbit Alfabeta, Bandung.

Sutrisno, Edy. 2014. Manajemen Sumber Daya Manusia. Jakarta: Prenada Media Group

Zainuddin. 2015. The Journalist. Jakarta : Prestasi Pustaka Publisher 